\title{
线性氟代烷烃电子相关能的基团加和性
}

\author{
司维江禚淑萍* \\ (山东理工大学化学工程学院, 山东 淄博２55049)
}

摘要：应用 Meld 程序在 MP2-OPT2/6-311++ $\mathrm{G}(d)$ 水平计算了线性氟代烷烃分子 $\mathrm{CH}_{3}\left(\mathrm{CH}_{2}\right)_{m} \mathrm{~F}(m=0-5)$ 中一 $\mathrm{CH}_{3}$ 、 $-\mathrm{CH}_{2}$ 一和一 $\mathrm{F}$ 基团电子相关能贡献值. 计算结果表明, 在 $\mathrm{CH}_{3}\left(\mathrm{CH}_{2}\right)_{m} \mathrm{~F}(m=0-5)$ 体系中, 端基一 $\mathrm{F} 、-\mathrm{CH}_{3}$ 基团电 子相关能贡献值 $E_{\mathrm{corr}}(-\mathrm{F})$ 和 $E_{\mathrm{corr}}\left(-\mathrm{CH}_{3}\right)$ 随着 $m$ 的增大而逐渐减小. 分子中 $\alpha$ 位置- $\mathrm{CH}_{2}$ 一基团电子相关能贡 献值 $E_{\mathrm{corr}}\left(-\mathrm{CH}_{2}-\right)$ 大于其他位置的贡献值. 通过计算结果可以推断, 在 $\mathrm{CH}_{3}\left(\mathrm{CH}_{2}\right)_{m} \mathrm{~F}$ 体系中随着 $m$ 的逐渐增大, 远离端基一 $\mathrm{F}$ 的一 $\mathrm{CH}_{2}$ 一基团电子相关能贡献值逐渐减小并将趋于不变, 此一 $\mathrm{CH}_{2}$ 一基团可看作一个标准的亚 甲基且其 $E_{\text {corr }}\left(-\mathrm{CH}_{2}\right.$ 一 的数值在 $\mathrm{CH}_{3}\left(\mathrm{CH}_{2}\right)_{m} \mathrm{~F}$ 体系中具有传递性. 应用 Meld 程序在 MP2-OPT2/6-311++ $\mathrm{G}(d)$ 水 平对 $\mathrm{CH}_{3}\left(\mathrm{CH}_{2}\right)_{m} \mathrm{~F}(m=2-5)$ 体系的计算结果和应用 Gaussian 98 程序在 MP2/6-311++ $\mathrm{G}(d) / / \mathrm{HF} / 6-311++\mathrm{G}(d)$ 水平对 $\mathrm{CH}_{3}\left(\mathrm{CH}_{2}\right)_{m} \mathrm{~F}(m=2-10)$ 体系的计算结果均表明, 体系总电子相关能与体系中 $(m-1)$ 数值呈线性关系.

关键词：相关能贡献；基团加和性；线性氟代烷烃

中图分类号：O641

\section{Additivity of Group Contribution of Electron Correlation Energies in Linear Alkyl Fluorides}

\author{
SI Wei-Jiang ZHUO Shu-Ping* \\ (School of Chemical Engineering, Shandong University of Technology, Zibo 255049, Shandong Province, P. R. China)
}

\begin{abstract}
Correlation energy contributions of the $-\mathrm{CH}_{3},-\mathrm{CH}_{2}-$ and $-\mathrm{F}$ functional groups in linear alkyl fluorides $\mathrm{CH}_{3}\left(\mathrm{CH}_{2}\right)_{m} \mathrm{~F}(m=0-5)$ were calculated and studied at MP2-OPT2/6-311++G $(d)$ level using Meld program. We found that with an increase in the number of intervening methylene groups in the studied systems, values of $E_{\text {corr }}(-\mathrm{F})$ and $E_{\text {corr }}\left(-\mathrm{CH}_{3}\right)$ decreased in the $\mathrm{CH}_{3}\left(\mathrm{CH}_{2}\right)_{m} \mathrm{~F}(m=0-5)$ series. Values of $E_{\text {corr }}\left(-\mathrm{CH}_{2}-\right)$ are different in different positions with respect to the $-\mathrm{F}$ group in the system. The value of $E_{\text {corr }}\left(-\mathrm{CH}_{2}-\right)$ for the $\alpha$ position is larger than the values for methylene groups in other positions within the same system. The farther the $-\mathrm{CH}_{2}-$ is from the $-\mathrm{F}$ group in the molecule, the smaller the value of $E_{\text {corr }}\left(-\mathrm{CH}_{2}-\right)$ is in $\mathrm{CH}_{3}\left(\mathrm{CH}_{2}\right)_{m} \mathrm{~F}(m=1-5)$ systems. We predict that with an increase in the number $m$ in the system, values of $E_{\text {cor }}\left(-\mathrm{CH}_{2}-\right)$, which are those of $-\mathrm{CH}_{2}-$ groups relatively far from the terminal -F group, would converge to the value of a "standard" $-\mathrm{CH}_{2}-$ group. This $E_{\text {corr }}\left(-\mathrm{CH}_{2}-\right)$ value is transferable between $\mathrm{CH}_{3}\left(\mathrm{CH}_{2}\right)_{m} \mathrm{~F}$ homologous systems. Results for $\mathrm{CH}_{3}\left(\mathrm{CH}_{2}\right)_{m} \mathrm{~F}(m=2-5)$ systems from Meld program at MP2-OPT2/6$311++\mathrm{G}(d)$ level and results for $\mathrm{CH}_{3}\left(\mathrm{CH}_{2}\right)_{m} \mathrm{~F}(m=2-10)$ systems from Gaussian 98 program at MP2/6-311++G $(d) / / \mathrm{HF} /$ $6-311++\mathrm{G}(d)$ level show that the total correlation energy is a linear function of $(m-1)$, where $m$ is the number of methylene groups in the system.
\end{abstract}

Key Words : Correlation energy contribution; Additivity of group contribution; Linear alkyl fluoride

It is known that one of the most important and difficult problems in electronic structure theory of molecules is the accurate and efficient description of the electron correlation energy in chemical bonds ${ }^{[1]}$. With the development of the computer science

Received: December 14, 2008; Revised: March 10, 2009; Published on Web: March 31, 2009.

*Corresponding author. Email: zhuosp@sdut.edu.cn; Tel: +86533-2780020.

山东省自然科学基金(Y2007B29)资助项目 
and quantum chemistry, a number of rigorous methods suitable for tackling the correlation problems have been develp ped, for instance, configuration interaction $(\mathrm{CI})^{[2]}$, multireference configuration interaction (MRCI) and the coupled cluster $(\mathrm{CC})$ procedures $^{[3]}$, which provide the practical means to calculate the electron correlation energy of small and moderate-sized molecules. For very large molecules, ab initio approaches are still computationally expensive or impossible due to the high computing power demand. Therefore, there has been significant research direct towards devising the linear-scaling methods for correlation energy calculations in the past decade and the development of linear scaling methods provided the rigorous alternative approaches which made the calculations of electron correlation energy possible for large molecules ${ }^{[4-11]}$. All these efforts are capable and successful to calculate the electron correlation energy of large molecules quite accurately but with much less computational cost. Based on the methodology of the theory of atoms in molecules (AIM) ${ }^{[12-14]}$, we have investigated the efficient scaling method for estimating the electron correlation energies for both strong ionic compounds and covalent molecules ${ }^{[15-18]}$. For the homologous organic molecules, according to the transferability and molecular similarity of atomic groups ${ }^{[19-25]}$, we studied the approximately transferable property of the correlation energies of methyl and methylene groups along the series of linear alkanes and developed the group additive scheme ${ }^{[2]]}$.

In this paper, we calculate the correlation energy contributions in terms of $-\mathrm{CH}_{3},-\mathrm{CH}_{2}-$ and $-\mathrm{F}$ functional groups in linear alkyl fluorides $\mathrm{CH}_{3}\left(\mathrm{CH}_{2}\right)_{m} \mathrm{~F}(m=0-5)$, then analyze the variability and transferability of these values from the viewpoint of bond and group properties. By investigating both results from Meld program at MP2-OPT2/6-311++G $(d)$ level for $\mathrm{CH}_{3}\left(\mathrm{CH}_{2}\right)_{m} \mathrm{~F}$ $(m=2-5)$ systems and from Gaussian 98 program at MP2/6-311++ $\mathrm{G}(d) / / \mathrm{HF} / 6-311++\mathrm{G}(d)$ level for $\mathrm{CH}_{3}\left(\mathrm{CH}_{2}\right)_{m} \mathrm{~F}(m=2-10)$ systems, we aim to formulate an additive group model which would predict the total correlation energy for large linear alkyl fluoride molecules. We believe that this approximation will be a useful means for the estimation of electron correlation energies of a wide variety of hydrocarbon derivative systems.

\section{Computation method}

The geometries of the linear alkyl fluorides studied in this paper were optimized by Gaussian 98 program $^{[27]}$ at HF/6-311++ $\mathrm{G}(d)$ level. The computations of the intrapair and interpair correlation energies were performed by the MP2-OPT2 method $^{[2,29]}$ in the Meld suite of electron code developed by Davidson et al. ${ }^{[30]}$.

According to the definition of correlation energy contribution of the individual electron pair to a system ${ }^{[1]}$, the correlation energy contribution of one functional group to the total system is de- fined as below,

$$
E_{\text {corr }}(g)=\sum_{i} E_{\text {corr }}(i)+[(1-\delta) / 2] \sum E_{\text {corr }}(p q)
$$

where $E_{\text {corr }}(g)$ is the correlation energy contribution of functional group $g$ to the system, $E_{\text {cor }}(i)$ is the correlation energy contribution of $i$ th electron pair, $E_{\text {corr }}(p q)$ is the correlation energy contribution of bonding electron pair between $p$ th atom in functional group $g$ and $q$ th atom in the other group which is bonded with functional group $g$ in the system, and $\delta$ is the charge of $g$ th group. As it is seen, Eq. (1) partitions the correlation energy among the functional groups. In this way, the total correlation energy of a molecular system can be summarized by the correlation energies of all the functional groups in the molecule.

\section{Results and discussion}

\subsection{Calculation of correlation energy contribution of a functional group}

In order to understand the correlation energy from the viewpoint of a functional group, we defined the correlation energy contribution of a functional group to a whole system as above. We take $\mathrm{CH}_{3} \mathrm{~F}$ as an example to illustrate the calculation details of the correlation energy contributions of $-\mathrm{CH}_{3}$ and $-\mathrm{F}$ groups in this molecule. Firstly, the intrapair and interpair correlation energies of $\mathrm{CH}_{3} \mathrm{~F}$ system were calculated by using MP2-OPT2 method in the Meld program using 6-311++ $\mathrm{G}(d)$ basis set. Then the correlation energy contributions of the individual electron pairs in the $\mathrm{CH}_{3} \mathrm{~F}$ system were computed. Finally, according to Eq.(1), the correlation energy contributions of functional groups $-\mathrm{F}$ and $-\mathrm{CH}_{3}$ in $\mathrm{CH}_{3} \mathrm{~F}$ molecule can be calculated with the following equations

$$
\begin{aligned}
& E_{\text {corr }}(-\mathrm{F})=E_{\text {corr }}\left(1 s_{\mathrm{F}}^{2}\right)+E_{\text {corr }}\left(2 s_{\mathrm{F}}^{2}\right)+2 E_{\text {corr }}\left(2 p_{\mathrm{F}}^{2}\right)+[(1-\delta) / 2] E_{\text {cor }}(\mathrm{C}-\mathrm{F})(2) \\
& E_{\text {corr }}\left(-\mathrm{CH}_{3}\right)=E_{\text {corr }}\left(1 s_{\mathrm{C}}^{2}\right)+3 E_{\text {corr }}(\mathrm{C}-\mathrm{H})+[(1-\delta) / 2] E_{\text {corr }}(\mathrm{C}-\mathrm{F})
\end{aligned}
$$

where $E_{\text {corr }}(-\mathrm{F})$ and $E_{\text {corr }}\left(-\mathrm{CH}_{3}\right)$ are the correlation energies of $-\mathrm{F}$ and $-\mathrm{CH}_{3}$ groups, $E_{\text {cor }}\left(1 s_{\mathrm{F}}^{2}\right)$, and $E_{\text {corr }}\left(1 s_{\mathrm{C}}^{2}\right)$ are the correlation energies of electron pairs in $1 s$ orbitals of $\mathrm{F}$ and $\mathrm{C}$ atoms, $E_{\text {corr }}\left(2 s_{\mathrm{F}}^{2}\right)$, $E_{\text {corr }}\left(2 p_{\mathrm{F}}^{2}\right)$ are those of electron pairs in $2 s, 2 p$ orbitals of $\mathrm{F}$ atoms, and $E_{\text {corr }}(\mathrm{C}-\mathrm{F})$ and $E_{\text {corr }}(\mathrm{C}-\mathrm{H})$ are the correlation energy contributions of $\mathrm{C}-\mathrm{F}$ and $\mathrm{C}-\mathrm{H}$ bonding electron pairs. $\delta$ is $-0.1847 e$ for $-\mathrm{F}$ group while it is $0.1847 e$ for $-\mathrm{CH}_{3}$ group. The results of total correlation energy of $\mathrm{CH}_{3} \mathrm{~F}$ system $E_{\text {corr }}$ (total), and correlation energies of $-\mathrm{F}$ and $-\mathrm{CH}_{3}$ groups $E_{\text {cor }}(-\mathrm{F})$ and $E_{\text {corr }}\left(-\mathrm{CH}_{3}\right)$ are shown in Table 1.

\subsection{Correlation energy contributions of $-\mathrm{F},-\mathrm{CH}_{3}$ and - $\mathrm{CH}_{2}$ - groups in $\mathrm{CH}_{3}\left(\mathrm{CH}_{2}\right)_{m} \mathbf{F}(m=0-5)$}

\subsubsection{Correlation energy contributions of $-F$ groups}

According to the definition of Eq.(1), the results of the correlation energy contributions of $-\mathrm{F}$ groups and the total correlation energies $E_{\text {corr }}$ (total) for $\mathrm{CH}_{3}\left(\mathrm{CH}_{2}\right)_{m} \mathrm{~F}(m=1-5)$ systems were cal-

Table 1 Correlation energy contributions of individual electron pairs and group contributions of $-\mathrm{CH}_{3}$ and $-\mathrm{F}$ in $\mathrm{CH}_{3}$ F with MP2-OPT2 method and 6-311++G(d) basis set

\begin{tabular}{ccccccccc}
\hline$E_{\text {corr }}\left(1 s_{\mathrm{C}}^{2}\right)$ & $E_{\text {corr }}(\mathrm{C}-\mathrm{H})$ & $E_{\text {corr }}(\mathrm{C}-\mathrm{F})$ & $E_{\text {corr }}\left(1 s_{\mathrm{F}}^{2}\right)$ & $E_{\text {corr }}\left(2 s_{\mathrm{F}}^{2}\right)$ & $E_{\text {corr }}\left(2 p_{\mathrm{F}}^{2}\right)$ & $E_{\text {corr }}\left(-\mathrm{CH}_{3}\right)$ & $E_{\text {corr }}(-\mathrm{F})$ & $E_{\text {corr }}($ total $)$ \\
\hline-17.54 & -53.03 & -78.35 & -17.97 & -44.45 & -58.09 & -208.56 & -225.00 & -433.56 \\
\hline
\end{tabular}

unit in millihartree $(\mathrm{mH}), E_{\text {corr }}($ total): the sum of the correlation energy contributions of all the functional groups 
Table 2 Correlation energy contributions in $\mathrm{CH}_{3}\left(\mathrm{CH}_{2}\right)_{m} \mathrm{~F}$

\begin{tabular}{|c|c|c|c|c|c|c|}
\hline \multicolumn{7}{|c|}{$(m=0-5)$ systems } \\
\hline & $\mathrm{CH}_{3} \mathrm{~F}$ & $\mathrm{C}_{2} \mathrm{H}_{5} \mathrm{~F}$ & $\mathrm{C}_{3} \mathrm{H}_{7} \mathrm{~F}$ & $\mathrm{C}_{4} \mathrm{H}_{9} \mathrm{~F}$ & $\mathrm{C}_{5} \mathrm{H}_{11} \mathrm{~F}$ & $\mathrm{C}_{6} \mathrm{H}_{33} \mathrm{~F}$ \\
\hline$\delta(\mathrm{F}) / e$ & -0.1847 & -0.1808 & -0.1805 & -0.1740 & -0.1680 & -0.1632 \\
\hline$E_{\mathrm{cor}}\left(-\mathrm{CH}_{3}\right)$ & $-208.56^{*}$ & -198.87 & -194.06 & -191.12 & -189.85 & -188.15 \\
\hline$E_{\mathrm{corr}}^{\alpha}\left(-\mathrm{CH}_{2}-\right)$ & & -187.23 & -186.85 & -186.25 & -185.73 & -185.13 \\
\hline $\bar{E}_{\mathrm{corr}}\left(-\mathrm{CH}_{2}-\right)$ & & & -175.14 & -172.65 & -170.51 & -168.40 \\
\hline$E_{\text {corr }}^{\beta}\left(-\mathrm{CH}_{2}-\right)$ & & & -175.14 & -174.85 & -173.86 & -172.75 \\
\hline$E_{\text {corr }}^{\gamma}\left(-\mathrm{CH}_{2}-\right)$ & & & & -170.45 & -169.82 & -169.17 \\
\hline$E_{\text {corr }}^{\delta}\left(-\mathrm{CH}_{2}-\right)$ & & & & & -167.85 & -166.82 \\
\hline$E_{\mathrm{corr}}^{e}\left(-\mathrm{CH}_{2}-\right)$ & & & & & & -164.87 \\
\hline$E_{\text {corr }}(-\mathrm{F})$ & -225.00 & -223.92 & -222.08 & -220.12 & -218.56 & -216.95 \\
\hline$E_{\text {corr }}$ (total) & -433.56 & -610.02 & -778.13 & -942.79 & -1105.67 & -1263.84 \\
\hline
\end{tabular}

culated by Eq. (2) which were listed in Table 2 and plotted in Fig.1.

It was found that with increase of the number $m$, the absolute values of correlation energy contribution of $-\mathrm{F}$ group decreased from $225.00 \mathrm{mH}$ in $\mathrm{CH}_{3} \mathrm{~F}$ to $216.95 \mathrm{mH}$ in $\mathrm{C}_{6} \mathrm{H}_{13} \mathrm{~F}$, which are not perfect transferable and show the dependence on the size of the molecule. It is noted that the less negative charge of $-\mathrm{F}$ group, the smaller the group correlation contribution of $-\mathrm{F}$ to $\mathrm{CH}_{3}\left(\mathrm{CH}_{2}\right)_{m} \mathrm{~F}(m=0-5)$.

2.2.2 Correlation energy contributions of $-\mathrm{CH}_{3}$ groups

Based on the definition of the group contribution of correlation energy in Eq.(1), the correlation energy contribution of terminal $-\mathrm{CH}_{3}$ group denoted in $E_{\text {corr }}\left(-\mathrm{CH}_{3}\right)$ in $\mathrm{CH}_{3}\left(\mathrm{CH}_{2}\right)_{m} \mathrm{~F}(m=$ $1-5)$ systems can be obtained by the following summation,

$$
E_{\text {corr }}\left(-\mathrm{CH}_{3}\right)=E_{\text {corr }}\left(1 s_{\mathrm{C}}^{2}\right)+3 E_{\text {corr }}\left(\mathrm{C}-\mathrm{H}_{3}\right)+1 / 2 E_{\text {corr }}(\mathrm{C}-\mathrm{C})
$$

where $E_{\mathrm{corr}}\left(1 s_{\mathrm{C}}^{2}\right)$ is the correlation energy contribution of electron pair in $1 s$ orbital of the terminal C atom while $E_{\text {corr }}\left(\mathrm{C}-\mathrm{H}_{3}\right)$ values are the average of the three primary $\mathrm{C}-\mathrm{H}$ bonding electron pairs in the terminal $-\mathrm{CH}_{3}$ group. Here is an assumption that all $\mathrm{C}-$ $\mathrm{C}$ bonds are equivalent in a linear alkyl fluoride system. According to Eq. (4), the results of the group contributions of $-\mathrm{CH}_{3}$ groups in $\mathrm{CH}_{3}\left(\mathrm{CH}_{2}\right)_{m} \mathrm{~F}(m=1-5)$ were listed in Table 2 and plotted in Fig.l.

It was found that the absolute values of the correlation energy contributions of $-\mathrm{CH}_{3}$ groups decreased from $208.56 \mathrm{mH}$ in $\mathrm{CH}_{3} \mathrm{~F}$ to $188.15 \mathrm{mH}$ in $\mathrm{C}_{6} \mathrm{H}_{13} \mathrm{~F}$. The variation of these values of $E_{\text {corr }}\left(-\mathrm{CH}_{3}\right)$ within these homologous molecules is significant so that the correlation energy contribution of $-\mathrm{CH}_{3}$ group does not exhibit the transferability due to their dependence on the length of the alkyl chain. With increase of the number $m$ of intervening $-\mathrm{CH}_{2}-$ groups in the chain, the absolute value of $E_{\text {corr }}\left(-\mathrm{CH}_{3}\right)$ becomes smaller. Compared with the numerical values of the correlation energy contributions of $-\mathrm{CH}_{3}$ groups in $\mathrm{CH}_{3}\left(\mathrm{CH}_{2}\right)_{m} \mathrm{CH}_{3}$ $(m=1-5)$ systems which are between -188.72 and -185.88 $\mathrm{mH}^{[26]}$, it is noted that the value of $E_{\text {corr }}\left(-\mathrm{CH}_{3}\right)$ in $\mathrm{C}_{6} \mathrm{H}_{13} \mathrm{~F}$ is $-188.15 \mathrm{mH}$, just falls in the range of the above corresponding values at the same level. It means that the remote effect of the perturbation introduced by $-\mathrm{F}$ group on terminal $-\mathrm{CH}_{3}$ group is gradually attenuated along the chain. The larger the number of $m$, the less effect of $-\mathrm{F}$ group on the value of $E_{\text {cor }}\left(-\mathrm{CH}_{3}\right)$.

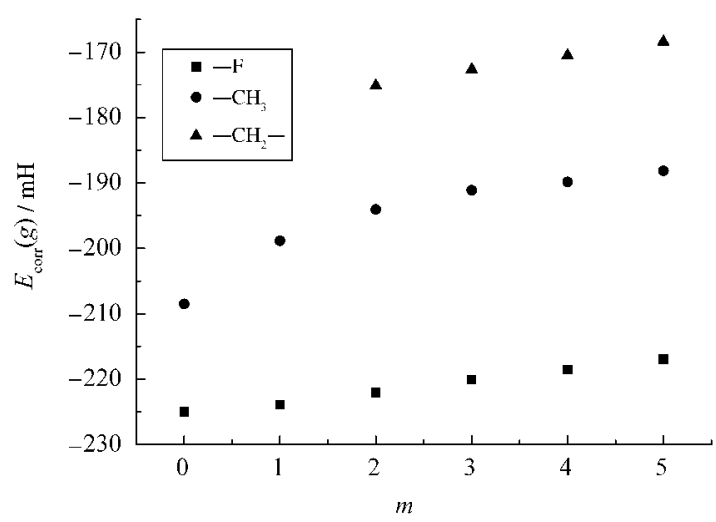

Fig.1 Plots of $\boldsymbol{E}_{\text {corr }}(-\mathbf{F}), \boldsymbol{E}_{\text {corr }}\left(-\mathrm{CH}_{3}\right)$ and $\overline{\boldsymbol{E}}_{\text {corr }}\left(-\mathrm{CH}_{2}-\right)$ against the number $m$ in $\mathrm{CH}_{3}\left(\mathrm{CH}_{2}\right)_{m} \mathrm{~F}$ systems

Therefore, it is predicted that if the number $m$ in $\mathrm{CH}_{3}\left(\mathrm{CH}_{2}\right)_{m} \mathrm{~F}$ system is relatively large enough, the correlation energy contribution of $-\mathrm{CH}_{3}$ group in the system would be intending to the same value as that in the corresponding alkane system. In fact, that is the result of the "inductive effect" of the functional group in organic molecules.

\subsubsection{Correlation energy contributions of $-\mathrm{CH}_{2}-$ groups}

It should be pointed out that in the calculation we note that the correlation energy contributions of $-\mathrm{CH}_{2}-$ group in different positions with respect to $-\mathrm{F}$ group show much difference in $\mathrm{CH}_{3}\left(\mathrm{CH}_{2}\right)_{m} \mathrm{~F}(m=0-5)$. Therefore, for clarity, the correlation energy contribution of $-\mathrm{CH}_{2}-$ group in $\alpha$ position is denoted with $E_{\text {corr }}^{\alpha}\left(-\mathrm{CH}_{2}-\right)$ and calculated by using,

$$
E_{\text {corr }}^{\alpha}\left(-\mathrm{CH}_{2}-\right)=E_{\text {corr }}\left(1 s_{\mathrm{C}}^{2}\right)+2 E_{\text {corr }}\left(\mathrm{C}-\mathrm{H}_{2}\right)+[(1-\delta) / 2] E_{\text {corr }}(\mathrm{C}-\mathrm{F})
$$

where $E_{\text {corr }}\left(1 s_{\mathrm{C}}^{2}\right)$ is the correlation energy contribution of $1 s$ electron pair of carbon atom of $-\mathrm{CH}_{2}-$ group in $\alpha$ position, $E_{\text {corr }}$ $\left(\mathrm{C}-\mathrm{H}_{2}\right)$ value is the average of the two secondary $\mathrm{C}-\mathrm{H}$ bonding electron pairs in $\alpha-\mathrm{CH}_{2}-$ group, and $E_{\text {corr }}(\mathrm{C}-\mathrm{F})$ is the correlation energy contributions of $\mathrm{C}-\mathrm{F}$ bonding electron pairs in $\mathrm{CH}_{3}\left(\mathrm{CH}_{2}\right)_{m} \mathrm{~F}(m=1-5)$ molecules. On the other hand, the contributions of the methylene groups in other positions rather than $\alpha$ position should include those contributions of one $1 s_{\mathrm{C}}^{2}$, two secondary $\mathrm{C}-\mathrm{H}$ and one $\mathrm{C}-\mathrm{C}$ electron pairs. Therefore, based on the assumption of all the $\mathrm{C}-\mathrm{C}$ bonds are equivalent in a linear alkyl fluoride system, the group contribution of these $-\mathrm{CH}_{2}-$ groups denoted in $E_{\text {corr }}\left(-\mathrm{CH}_{2}-\right)$ can be obtained by summarizing the values of $E_{\text {corr }}\left(1 s_{\mathrm{C}}^{2}\right), E_{\text {corr }}\left(\mathrm{C}-\mathrm{H}_{2}\right)$ and $E_{\text {corr }}(\mathrm{C}-\mathrm{C})$, i.e.,

$$
E_{\text {corr }}\left(-\mathrm{CH}_{2}-\right)=E_{\text {corr }}\left(1 s_{\mathrm{C}}^{2}\right)+2 E_{\text {corr }}\left(\mathrm{C}-\mathrm{H}_{2}\right)+E_{\text {corr }}(\mathrm{C}-\mathrm{C})
$$

Because the correlation energy contribution of $\mathrm{C}-\mathrm{F}$ bonding electron pair is larger than that of $\mathrm{C}-\mathrm{C}$ bonding, the absolute value of $E_{\text {corr }}^{\alpha}\left(-\mathrm{CH}_{2}-\right)$ of $-\mathrm{CH}_{2}-$ group in $\alpha$ position is larger than those values of $E_{\text {corr }}\left(-\mathrm{CH}_{2}-\right)$ of other methylene groups and shows much difference in the same $\mathrm{CH}_{3}\left(\mathrm{CH}_{2}\right)_{m} \mathrm{~F}(m=1-5)$ molecule. Therefore, we defined the average value of all $-\mathrm{CH}_{2}-$ groups except the $\alpha-\mathrm{CH}_{2}-$ group in a molecule denoted with $\bar{E}_{\text {corr }}\left(-\mathrm{CH}_{2}-\right)$ and obtained by

$$
\bar{E}_{\text {corr }}\left(-\mathrm{CH}_{2}-\right)=\sum_{m} E_{\text {corr }}\left(-\mathrm{CH}_{2}-\right) /(m-1)
$$

where $(m-1)$ is the number of $-\mathrm{CH}_{2}-$ groups except the $\alpha$ 
$-\mathrm{CH}_{2}-$ group in the linear alkyl fluoride molecule.

Thus, the numerical result of group contributions of methylene groups in $\alpha, \beta, \gamma, \delta$ and $\varepsilon$ positions denoted with $E_{\text {corr }}^{\alpha}\left(-\mathrm{CH}_{2}-\right)$, $E_{\text {corr }}^{\beta}\left(-\mathrm{CH}_{2}-\right), E_{\text {corr }}^{\gamma}\left(-\mathrm{CH}_{2}-\right), E_{\text {corr }}^{\delta}\left(-\mathrm{CH}_{2}-\right)$, and $E_{\text {corr }}^{\varepsilon}\left(-\mathrm{CH}_{2}-\right)$ calculated by the above equations for $\mathrm{CH}_{3}\left(\mathrm{CH}_{2}\right)_{m} \mathrm{~F}(m=1-5)$ are listed in Table 2. The average values $\bar{E}_{\text {corr }}\left(-\mathrm{CH}_{2}-\right)$ for $\mathrm{CH}_{3}\left(\mathrm{CH}_{2}\right)_{m} \mathrm{~F}(m=1-5)$ systems are given in Table 2 and plotted in Fig.1 as well.

As it is seen in Table 2, the group contribution values of $E_{\text {corr }}\left(-\mathrm{CH}_{2}-\right)$ in different positions of different molecules show somewhat differences in $\mathrm{CH}_{3}\left(\mathrm{CH}_{2}\right)_{m} \mathrm{~F}(m=1-5)$ series. The absolute value of correlation energy contributions of $-\mathrm{CH}_{2}-$ groups in $\alpha$ position $E_{\text {corr }}^{\alpha}\left(-\mathrm{CH}_{2}-\right)$ are 187.23, 186.85, 186.25, 185.73 and $185.13 \mathrm{mH}$ from $\mathrm{C}_{2} \mathrm{H}_{5} \mathrm{~F}$ to $\mathrm{C}_{6} \mathrm{H}_{13} \mathrm{~F}$ systems, which are larger than those absolute values of $E_{\text {corr }}\left(-\mathrm{CH}_{2}-\right)$ in other positions in the same molecule, therefore the $-\mathrm{CH}_{2}-$ group in $\alpha$ position is the nearest and most perturbed group by "inductive effect" of $-\mathrm{F}$ group which essentially produces a nearestneighbor effect in $\mathrm{CH}_{3}\left(\mathrm{CH}_{2}\right)_{m} \mathrm{~F} \quad(m=1-5)$ series. In the discussion of group contributions of $-\mathrm{CH}_{2}-$ groups in other positions, it was found that with the increase of the number $m$ of intervening $-\mathrm{CH}_{2}-$ groups in the system, all the absolute values of $E_{\text {corr }}\left(-\mathrm{CH}_{2}-\right)$ decrease from $\mathrm{C}_{3} \mathrm{H}_{7} \mathrm{~F}$ to $\mathrm{C}_{6} \mathrm{H}_{13} \mathrm{~F}$ system, i.e., the longer the alkyl chain, the smaller the group contribution of $-\mathrm{CH}_{2}-$ groups at the same position in different molecules. Compared the correlation energy $-164.87 \mathrm{mH}$ of $-\mathrm{CH}_{2}-$ group in $\varepsilon$ position connected with the terminal $-\mathrm{CH}_{3}$ group in $\mathrm{C}_{6} \mathrm{H}_{13} \mathrm{~F}$ molecule with the corresponding value $-161.11 \mathrm{mH}^{[26]}$ in $\mathrm{C}_{6} \mathrm{H}_{14}$ molecule, it was noted that the difference comes from the remote effect of $-\mathrm{F}$ group. Therefore, it was suggested that with the increase of the number $m$ of methylene groups in the linear alkyl flouride system, the value of the methylene group relatively far from the $-\mathrm{F}$ group would approach the value of methylene group in the corresponding alkane molecule, which could be considered as a "standard" methylene group ${ }^{[25]}$. In that way, the corresponding quantity of group contribution of a "standard" methylene group could be used as the transferable value in dif-ferent homologous molecules.

\subsection{Additivity of group property for linear alkyl fluoride}

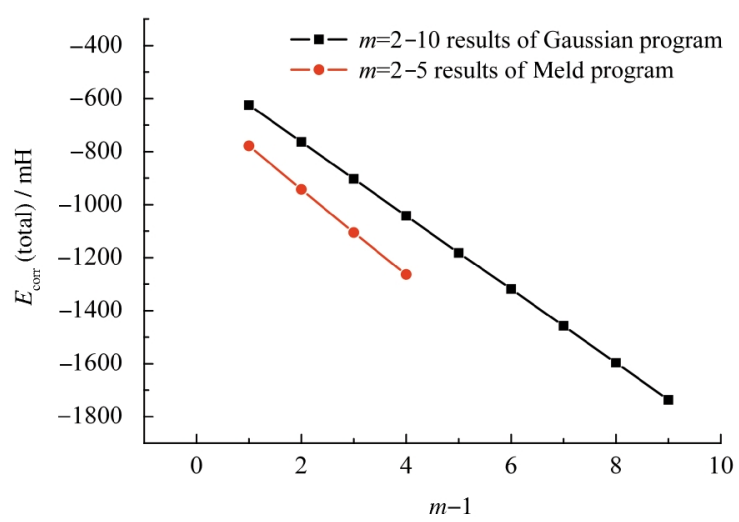

Fig.2 Plots of $E_{\text {corr }}($ total) against the number $(m-1)$ in $\mathrm{CH}_{3}\left(\mathrm{CH}_{2}\right)_{m} \mathrm{~F}$ with Meld and Gaussian programs
Although the correlation energy contributions of methyl and methylene groups exhibit a clear dependence on the length of chain and the position with respect to $-\mathrm{F}$ group in the system, with the increase of the number of methylene groups, the value of a "standard" $-\mathrm{CH}_{2}-$ group would show the transferable property in the homologous fluoride series. Therefore, the total correlation energies $E_{\text {corr }}$ (total) of the homologous series $\mathrm{CH}_{3}\left(\mathrm{CH}_{2}\right)_{m} \mathrm{~F}$ can be expressed as a linear function of its number of methylene groups, starting with $m=2$,

$E_{\text {corr }}($ total $)=A+(m-1) B$

where $A$ is the summation of the correlation energy contributions of methyl, methylene in $\alpha$ position and fluorine groups, and $B$ is the average value of $\bar{E}_{\text {corr }}\left(-\mathrm{CH}_{2}-\right)$ of methylene groups in the positions except $\alpha$ position. The fitting equation for $\mathrm{CH}_{3}\left(\mathrm{CH}_{2}\right)_{m} \mathrm{~F}$ ( $\left.m=2-5\right)$ systems using the results of MP2-OPT2 method by Meld program with 6-311++G(d) method is as follows,

$$
E_{\text {cor }}(\text { total })=-613.06-163.52(m-1)
$$

where $A=-613.06 \mathrm{mH}$ and $B=-163.52 \mathrm{mH}$, which is plotted in Fig.2.

As seen in Fig.2, a high correlativity is reflected in the large correlation coefficient $R^{2}=0.9999$. The constants $A$ and $B$ can be rationalized in terms of the above values of $E_{\text {cor }}(-\mathrm{F}), E_{\text {corr }}\left(-\mathrm{CH}_{3}\right)$ and $E_{\mathrm{cor}}\left(-\mathrm{CH}_{2}-\right)$ of fluorine, methyl and methylene groups. It should be pointed out that the values of $A$ and $B$ depend on the level of the method and basis set used in the calculation. It is interesting that the value of slope $B$, which is $-163.52 \mathrm{mH}$, is just between the values of $E_{\text {corr }}\left(-\mathrm{CH}_{2}-\right)$ in $\mathrm{C}_{5} \mathrm{H}_{12}$ and $\mathrm{C}_{6} \mathrm{H}_{14}$ molecules, which are -164.84 and $-161.11 \mathrm{mH}$, at the same level ${ }^{[26}$. Therefore it could be easily predicted that with the increase of the number of $-\mathrm{CH}_{2}-$ groups in linear alkyl fluorides, the value of $E_{\text {corr }}\left(-\mathrm{CH}_{2}-\right)$ of the methylene group would converge to a constant value, thus this group could be taken as the "standard" $-\mathrm{CH}_{2}-$ group and the value of $E_{\text {corr }}\left(-\mathrm{CH}_{2}-\right)$ is transferable in the long linear alkyl fluorides. It is indicated that the total correlation energy of the linear alkyl fluoride molecules could be estimated by using the additivity of the group contributions.

For the test and application of group contribution model, we calculated the correlation energies of $E_{\text {corr }}$ (total) for $\mathrm{CH}_{3}\left(\mathrm{CH}_{2}\right)_{m} \mathrm{~F}$ $(m=2-10)$ linear alkyl fluorides at MP2/6-311++G $(d) / / \mathrm{HF} / 6$ $311++\mathrm{G}(d)$ level by Gaussian 98 program, the results is listed in Table 3.

Therefore, the total correlation energies $E_{\text {corr }}$ (total) of $\mathrm{CH}_{3}\left(\mathrm{CH}_{2}\right)_{m} \mathrm{~F}$ $(m=2-10)$ systems can be fitted by the following equation,

$$
E_{\text {cor }}(\text { total })=-485.56-138.98(m-1)
$$

which is plotted in Fig.2. where $R^{2}=1.0000$ indicates the excellent fitting relationship. The constant $-138.98 \mathrm{mH}$ is corresponded to the average value of $\bar{E}_{\text {corr }}\left(-\mathrm{CH}_{2}-\right)$ of methylene groups in the positions except $\alpha$ position, and constant -485.56 $\mathrm{mH}$ is corresponded to the summation of values of $E_{\text {corr }}(-\mathrm{F})$, $E_{\text {corr }}\left(-\mathrm{CH}_{3}\right)$ and $E_{\text {corr }}^{\alpha}\left(-\mathrm{CH}_{2}-\right)$. It means that the total correlation energy of a linear alkyl fluoride molecule can be obtained by the summation of group contributions of $-\mathrm{CH}_{3},-\mathrm{F}$ and $-\mathrm{CH}_{2}-$ groups. In a large $\mathrm{CH}_{3}\left(\mathrm{CH}_{2}\right)_{m} \mathrm{~F}$ molecule, the total correlation energy is proportional to the number of methylene groups and the 
Table 3 Results of group contribution model and the absolute errors for $\mathrm{CH}_{3}\left(\mathrm{CH}_{2}\right)_{m} \mathrm{~F}(m=2-10)$ systems

\begin{tabular}{lccccccccc}
\hline & $\mathrm{C}_{3} \mathrm{H}_{7} \mathrm{~F}$ & $\mathrm{C}_{4} \mathrm{H}_{9} \mathrm{~F}$ & $\mathrm{C}_{5} \mathrm{H}_{11} \mathrm{~F}$ & $\mathrm{C}_{6} \mathrm{H}_{13} \mathrm{~F}$ & $\mathrm{C}_{7} \mathrm{H}_{15} \mathrm{~F}$ & $\mathrm{C}_{8} \mathrm{H}_{17} \mathrm{~F}$ & $\mathrm{C}_{9} \mathrm{H}_{19} \mathrm{~F}$ & $\mathrm{C}_{10} \mathrm{H}_{21} \mathrm{~F}$ & $\mathrm{C}_{11} \mathrm{H}_{23} \mathrm{~F}$ \\
\hline$E_{\text {cor }}$ (total) $/ \mathrm{mH}$ & -624.04 & -763.36 & -902.89 & -1042.41 & -1181.97 & -1318.46 & -1457.78 & -1597.11 & -1736.44 \\
$E_{\text {corr }}($ estimated $) / \mathrm{mH}$ & -624.54 & -763.52 & -902.50 & -1041.48 & -1180.46 & -1319.44 & -1458.42 & -1597.40 & -1736.38 \\
$\Delta E_{\text {cor }} / \mathrm{mH}$ & -0.50 & -0.16 & 0.39 & -0.93 & 1.51 & -0.98 & -0.64 & -0.29 & 0.06 \\
\hline
\end{tabular}

slope $B$ is the group contribution of a "standard" $-\mathrm{CH}_{2}-$ group to the whole system. The standard error of these estimated results by fitting equation is $0.63 \mathrm{mH}$. From Table 3 it is seen that the absolute errors by the group contribution model with Eq. (10) are also very small. Therefore, by using this group contribution model we can estimate the total correlation energies of very large linear alkyl fluorides. At present, with the limitation of the computation capacity for very large molecular systems, the group additive scheme is promising for estimating the correlation energy of larger linear alkyl fluoride molecules.

\section{Conclusions}

(1) The correlation energy contributions of $-\mathrm{CH}_{3},-\mathrm{CH}_{2}-$ and $-\mathrm{F}$ groups were calculated in $\mathrm{CH}_{3}\left(\mathrm{CH}_{2}\right)_{m} \mathrm{~F}(m=0-5)$ alkyl fluorides. It reveals that with the increase of number of the intervening methylene groups in the system, the absolute values of group contributions of $E_{\text {corr }}(-\mathrm{F})$ and $E_{\text {corr }}\left(-\mathrm{CH}_{3}\right)$ decrease in $\mathrm{CH}_{3}\left(\mathrm{CH}_{2}\right)_{m} \mathrm{~F}(m=0-5)$ series. The absolute value of $E_{\text {corr }}\left(-\mathrm{CH}_{2}-\right)$ in the $\alpha$ position is larger than those of methylene groups in other positions in the same system. In the $\mathrm{CH}_{3}\left(\mathrm{CH}_{2}\right)_{m} \mathrm{~F}$ (m=0-5) systems discussed in the text, it is found that the farther the methylene group from the $-\mathrm{F}$ group in the molecule, the smaller the value of $E_{\text {corr }}\left(-\mathrm{CH}_{2}-\right)$. It is inferred that the value of $E_{\text {corr }}\left(-\mathrm{CH}_{2}-\right)$ of a "standard" $-\mathrm{CH}_{2}-$ group should be a constant independent of the length of a chain at a certain level with given basis sets, which would be transferable in the long linear alkyl fluoride systems.

(2) Due to the transferable property of the "standard" $-\mathrm{CH}_{2}-$ groups, the excellent fitting relationship between the total correlation energies $E_{\text {corr }}$ (total) for $\mathrm{CH}_{3}\left(\mathrm{CH}_{2}\right)_{m} \mathrm{~F}$ and $(m-1)$, where $m$ is the number of $-\mathrm{CH}_{2}-$ groups was obtained. It is predicted that while $m$ is large enough, the total correlation energy of a $\mathrm{CH}_{3}\left(\mathrm{CH}_{2}\right)_{m} \mathrm{~F}$ molecule follows a simple additive group contribution model as a linear function of $(m-1)$, which provides a direction for the estimation of the total correlation energies of very large linear fluoride systems.

\section{References}

1 Rassolov, V. A.; Ratner, M. A.; Pople, J. A. J. Chem. Phys., 2000, 112: 4014

2 Lowdin, P. O. Adv. Chem. Phys., 1959, 2: 207

3 Yarkony, D. R. Modern electronic structure theory. Singapore: World Scientific, 1995, Part 1 and 2

4 Deev, V.; Collins, M. A. J. Chem. Phys., 2005, 122: 154102

5 Ramachandran, B. J. Phys. Chem. A, 2006, 110(2): 396
6 Fedorov, D. G.; Kitaura, K. J. Chem. Phys., 2004, 121: 2483

7 Laidig, W. D.; Purvis, G. D.; Bartlett, R. J. J. Phys. Chem., 1985, 89: 2161

8 Schutz, M.; Werner, H. J. Chem. Phys. Lett., 2000, 318: 370

9 Schutz, M. Phys. Chem. Chem. Phys., 2002, 4: 3941

10 Maslen, P. E.; Lee, M. S.; Head-Gordon, M. Chem. Phys. Lett., 2000, 319: 205

11 Stoll, H. Phys. Rev. B, 1992, 46: 6700

12 Cortes-Guzman, F.; Bader, R. F. W. Chem. Phys. Lett., 2003, 379: 183

13 Bader, R. F. W. Can. J. Chem., 1999, 77: 86

14 Bader, R. F. W. Chem. Rev., 1991, 91: 893

15 Zhuo, S. P.; Wei, J. C.; Wei, Z. R.; Ju, G. Z. J. Chem. Phys., 2002, 117(5): 1956

16 Zhuo, S. P.; Wei, J. C.; Ju, G. Z. J. Phys. Chem. A, 2004, 108(1): 127

17 Zhuo, S. P.; Wei, J. C.; Ju, G. Z. J. Phys. Chem. A, 2001, 105(21): 5255

18 Zhuo, S. P.; Wei, J. C.; Ju, G. Z. J. Chem. Phys., 2001, 115(19): 8298

19 Vila, A.; Carballo, E.; Mosquera, R. A. Can. J. Chem., 2000, 78: 1535

20 Cioslowsky, J.; Nanayakkara, A. J. Am. Chem. Soc., 1993, 115: 11213

21 Cioslowsky, J.; Stefanov, B. B.; Constans, P. J. Comput. Chem., 1996, 17: 1352

22 Bader, R. F. W.; Popelier, P. L. A.; Chang, C. J. Mol. Struct. Theochem, 1992, 255: 145

23 Bader, R. F. W.; Popelier, P. L. A.; Keith, T. A. Angew. Chem. Int. Ed. Engl., 1994, 33: 620

24 Wiberg, K. B.; Bader, R. F. W.; Lau, C. D. H. J. Am. Chem. Soc., 1987, 109: 1001

25 Benson, S. W.; Buss, J. H. J. Chem. Phys., 1958, 29: 546

26 Zhuo, S. P.; Wei, J. C.; Ju, G. Z. J. Chem. Phys., 2004, 120(6): 2575

27 Frisch, M. J.; Trucks, G. W.; Schlegel, H. B.; et al. Gaussian 98, Revision A.07. Pittsburgh PA: Gaussian, Inc., 1998

28 Murray, C.; Davidson, E. R. Chem. Phys. Lett., 1991, 187: 451

29 Murray, C.; Davidson, E. R. Int. J. Quantum. Chem., 1992, 43: 755

30 The MELD collection of electronic structure codes was developed by McMurchie, L. E.; Elbert, S. T.; Langhoff, S. R.; Davidson, E. R.; Feller, D.; Rawlings, D. C. Meld program. Indiana: Indiana University, 2001 